\title{
Pesquisa sobre ensino na saúde: diversidade regional, interdisciplinaridade e multiplicidade temática
}

\author{
Marco Akerman ${ }^{1,2}$, Erik Montagna ${ }^{2,3}$, Lídia Ruiz-Moreno ${ }^{4}$ \\ Editores convidados - Fascículo Temático "Pesquisa sobre Ensino na Saúde" \\ 'Faculdade de Saúde Pública, Universidade de São Paulo (USP) - São Paulo (SP), Brasil. \\ ${ }^{2}$ Núcleo de Ensino e Pesquisa em Educação na Saúde, Faculdade de Medicina do ABC (FMABC) - Santo André (SP), Brasil. \\ ${ }^{3}$ Faculdades Oswaldo Cruz (FOC) - São Paulo (SP), Brasil. \\ Centro de Desenvolvimento do Ensino Superior em Saúde, Universidade Federal de São Paulo (UNIFESP) - São Paulo (SP), Brasil.
}

DOI: http://dx.doi.org/10.7322/abcshs.v40i3.786

Em 1993, Paulo Freire escreveu uma carta aos professores: "A quem ousa ensinar"1. Afirma que o ato de ensinar não pode prescindir daquele que aprende, e "quero dizer que ensinar e aprender se vão dando de tal maneira que quem ensina aprende, de um lado, porque reconhece um conhecimento antes aprendido e, de outro, porque, observado a maneira como a curiosidade do aluno aprendiz trabalha para apreender o ensinando-se, sem o que não o aprende, o ensinante se ajuda a descobrir incertezas, acertos, equívocos".

Mergulhar no campo da pesquisa sobre ensino na saúde é, sem sombra de dúvida, trabalhar com o binômio ensinar-aprender, mas antes de tudo descobrir que incertezas permanecem nos dias de hoje (e que talvez se perpetuem!), que acertos estão sendo feitos (são muitos!), primeiramente redirecionando caminhos para que os equívocos cometidos não se repitam (insistir no erro é teimosia!).

E foi dentro desse espírito que o Edital Pró-Ensino na Pesquisa, apoiado pela Coordenação de Aperfeiçoamento de Pessoal de Nível Superior (CAPES) e pelo Ministério da Saúde (MS), foi lançado em 2010 e que o Núcleo de Ensino e Pesquisa em Educação na Saúde (NEPES) da Faculdade de Medicina do ABC (FMABC) foi criado. Esse não é um exercício simples e, portanto, clama por múltiplas visões e experiências em distintos contextos.

Imbuído dessa perspectiva, o NEPES da FMABC, em parceria com o Centro de Desenvolvimento do Ensino Superior em Saúde (CEDESS) da Universidade Federal de São Paulo (UNIFESP), organizou o presente número temático dos Arquivos Brasileiros de Ciências da Saúde (ABCS Health Sciences), que conta com pesquisas sobre o ensino na saúde com ampla multiplicidade temática, visão interdisciplinar, abrangência regional e lócus de atuação em organizações públicas, privadas, nacionais e internacionais representadas em artigos originais, artigos de revisão e relatos de experiência.

O tema parece ser de interesse tanto das instituições de ensino superior (IESs) públicas quanto privadas, uma vez que pesquisadores de ambas as organizações reverberaram suas contribuições, assim como parece estar na agenda internacional, pois há um relato de experiência que inclui consultora da Organização Pan-Americana da Saúde (OPAN) e um artigo que debate a internacionalização do ensino superior.

Nem sempre reproduzir uma experiência que acontece ali poderá funcionar acolá. O contexto importa na implementação de resultados de pesquisas sobre ensino na saúde. Aspectos culturais, sociais, políticos e linguísticos podem influenciar em como os empreendimentos são desenvolvidos; contudo, compartilhar saberes e trocar de experiências valoriza as práticas e estimula mudanças.

Nesse sentido, o número temático que você tem em mãos amplia essa visão trazendo a voz de pesquisadores de todas as Regiões do Brasil: Norte (Pará), Nordeste (Ceará, Piauí e Pernambuco), Centro-Oeste (Brasília e Goiás), Sul (Rio Grande do Sul) e Sudeste (Minas Gerais, Rio de Janeiro e São Paulo).

Alguns autores, como, por exemplo, Edgar Morin², propugnam criar lógicas de articulação e convergências de talentos, ações e recursos que sejam capazes de enfrentar a complexidade dos problemas contemporâneos. A interdisciplinaridade tem sido proposta como um dispositivo para enfrentar a desfragmentação do saber e das práticas ${ }^{3}$. Se nos séculos XIX e XX dividíamos para compreender o corpo humano, as células, seus núcleos e o DNA para chegar aos genes, no século XXI temos de juntar todas essas partes de novo para entender o todo.

Para contrapor o sentido do ensino tradicional, Cunha traz o que denomina de nova proposta, a abordagem educacional que faz referência ao paradigma emergente. Nessa perspectiva, podemos destacar o conhecimento como provisório, relativo e historicamente construído.

Essa concepção traduz a ideia de movimento, transitoriedade, vida. Assim, o conhecimento volta a ser produto das necessidades e contradições humanas e sociais. A análise e a capacidade de compor e recompor dados, informações, argumentos e ideias são estimuladas. A curiosidade, o questionamento exigente e a incerteza são valorizados. A dúvida, assim como o erro, antes de ser punida, é parte integrante do processo de aprendizagem e impulso do pensamento. A pesquisa é instrumento de ensino e a extensão torna-se o ponto de partida e chegada para apreensão da realidade ${ }^{4}$. 
Os artigos deste suplemento fortalecem esse desiderato e mostram robusta interação interdisciplinar. Somos pedagogos, biólogos, farmacêuticos, fisioterapeutas, dentistas, médicos, enfermeiros, jornalistas, sociólogos, psicólogos, terapeutas ocupacionais, educadores físicos, etc. em prol do trabalho interprofissional e do fortalecimento do trabalho em equipe. O campo da pesquisa sobre ensino na saúde clama por múltiplos olhares sobre múltiplos objetos.

O número temático que produzimos também atende a essa demanda e olha para a formação na graduação dos profissionais de saúde, com ênfase na Medicina, Fisioterapia, Enfermagem, Terapia Ocupacional e Gestão Hospitalar. O currículo baseado em competências é um dos focos destas pesquisas.

A pós-graduação também comparece como objeto de estudo com análises sobre as Residências Multiprofissionais em Saúde, a formação docente nos programas de Mestrado Profissional e as especializações lato sensu em saúde da família/atenção básica (AB). A busca das identidades profissionais é um tema candente e há um artigo sobre tal tema em relação aos médicos generalistas.

Os cenários de ensino são problematizados, com destaque para a AB/atenção primária em saúde, debatendo-se sua capacidade de veicular imaginários de integralidade versus projetos reducionistas de práticas fragmentadas.

Dispositivos para estimular metodologias ativas, como portfólios, oficinas, monitorias, gincanas, etc., são analisados.

A extensão universitária, patinho feio da tríade ensino-pesquisa-extensão, também é abordada de maneira crítica nos seus avanços e limites, tendo em mente que a universidade deve alcançar seu ápice quando “o príncipe, a pesquisa, beijar o sapo, a extensão", como menciona Renato Janine Ribeiro no prefácio do livro Universidade Nova: Textos Críticos e Esperançosos 5 . A famosa indissociabilidade entre pesquisa, ensino e extensão.

Os agentes comunitários de saúde têm lugar privilegiado em alguns estudos como "preceptores" no processo de ensino-aprendizagem na graduação dos profissionais de saúde, e a educação permanente ganha destaque como interface importante na relação ensino-serviço-comunidade.

O artigo principal deste suplemento nos confronta com a pergunta "Há pesquisa sobre ensino na saúde no Brasil?”6 e nos oferece a seguinte resposta:

Há pesquisa sobre ensino na saúde no Brasil e elas estão sinalizando para a necessidade de sua sustentabilidade e consolidação. Para que sigam produzindo respostas aos dilemas e às inquietações que justificou o lançamento do Edital CAPES/MS, há que se reivindicar e promover a inclusão da questão do ensino na saúde na agenda de prioridades das instituições de ensino, governamentais e de fomento à pesquisa e dos próprios docentes e preceptores. Se por um lado existem oportunidades que devem ser aproveitadas e potencializadas, como o desenvolvimento de processos de formação docente exigidos nas Novas Diretrizes Curriculares Nacionais dos Cursos de Medicina fruto do Programa Mais Médicos, e que podem ser articulado a um pujante processo de produção de conhecimento sobre o ensino em saúde, por outro seria importante, por exemplo, agregar essa temática à Agenda de Prioridades em Pesquisas em Saúde e na retomada dos termos que podem indicar temas e questões a serem aprofundadas pelas instituições de ensino e pesquisa brasileiras nos próximos anos. Devemos garantir pesquisa, formação e inovação no ensino na saúde se pretendemos realizar a profunda mudança nos modelos de formação profissional que a população e o SUS demandam e precisam.

E a FMABC promove esse tema na sua agenda de pesquisa? Há muito ainda por fazer nesse campo na FMABC. Olhando retrospectivamente para todas as dissertações e teses produzidas pelo Programa de Ciências da Saúde da FMABC, desde 2003, encontramos 20 pesquisas que poderiam ser classificadas como “ensino na saúde", uma proporção ainda muito pequena em relação ao número total de pesquisas realizadas, em torno de 220.

Com o NEPES e este número temático aspiramos estimular o tema na agenda de pesquisa da FMABC. Como analisadores entraram neste suplemento artigos que estudaram: a residência multiprofissional; atenção primária no internato da Medicina; estágios em Terapia Ocupacional; o uso de novas tecnologias na graduação; linha do tempo das mudanças curriculares na Medicina; a Saúde Coletiva; esforços interdisciplinares; o novo curso de graduação em gestão hospitalar; a extensão e iniciativas de apoio discente-docente.

Faça bom proveito desta leitura. Extraia ideias, dúvidas, certezas, afirmações, discordâncias, inquietações. Não faça desta leitura apenas um exercício teórico, reflita sobre sua prática na direção de constituir uma verdadeira práxis que transforme profundamente o processo de ensino-aprendizagem nas profissões da saúde.

A população brasileira clama por um profissional de saúde sensível, sensato, com uma escuta qualificada que solidariamente e de maneira genuína esteja aberto para compartilhar angústias e soluções individuais e coletivas que produzam vida cheia de potência e alegria.

\section{REFERÊNCIAS}

1. Freire P. Carta de Paulo Freire aos professores. Estud Av. 2001;15(42):259-68.

2. Morin E. Os sete saberes necessários à educação do futuro. São Paulo: Cortez; 2000.

3. Almeida Filho N. Transdisciplinaridade e o paradigma pós-disciplinar na saúde. Saúde Soc. 2005;4(3):30-50. http://dx.doi.org/10.1590/S0104-12902005000300004
4. Cunha Ml. O professor universitário na transição de paradigmas. $2^{a}$ ed. Araraquara: Junqueira \& Marin; 2005.

5. Almeida Filho N. Universidade nova: textos críticos e esperançosos. Brasília: UNB; 2007.

6. Cyrino EG, Pinto HA, Oliveira FP, Figueiredo AM, Parreira CMSF. Há Pesquisa de Ensino na Saúde no Brasil? ABCS Health Sci. 2015;40(3):146-55.

http://dx.doi.org/10.7322/abcshs.v40i3.787 